\title{
Calix[4]quinones Derived from Double Calix[4]arenes: \\ Synthesis, Complexation and Electrochemical Properties towards Alkali Metal Ions
}

Nattavut Kerdpaiboon, Boosayarat Tomapatanaget, Orawon Chailapakul, and Thawatchai Tuntulani*

\section{Supporting Information}

Page S2: General Experiment Methods.

Page S3: Fig S1. ${ }^{1} \mathrm{H}$ NMR (200 MHz) spectra of receptor 1 in the presence of $\mathrm{Li}^{+}$.

Page S4: Fig S2. ${ }^{1} \mathrm{H}$ NMR (200 MHz) spectra of receptor 1 in the presence of $\mathrm{K}^{+}$.

Page S5: Fig S3. ${ }^{1} \mathrm{H}$ NMR (200 MHz) spectra of receptor 2 in the presence of $\mathrm{Li}^{+}$.

Page S6: Fig S4. ${ }^{1} \mathrm{H}$ NMR (200 MHz) spectra of receptor 2 in the presence of $\mathrm{Na}^{+}$.

Page S7: Fig S5. ${ }^{1} \mathrm{H}$ NMR (200 MHz) spectra of receptor 2 in the presence of $\mathrm{K}^{+}$.

Page S8: Fig S6. ${ }^{1} \mathrm{H}$ NMR (400 MHz) spectra of receptor 2 in the presence of $\mathrm{Cs}^{+}$.

Page S9: Fig S7. Square wave voltammograms of 2 in the presence of $\mathrm{Na}^{+}$.

Page S10: Fig S8. Square wave voltammograms of 2 in the presence of $\mathrm{K}^{+}$.

Page S11: Fig S9. Square wave voltammograms of 2 in the presence of $\mathrm{Cs}^{+}$.

Page S12: Fig S10. Square wave voltammograms of $\mathbf{3}$ in the presence of $\mathrm{Na}^{+}$.

Page S13: Fig S11. Square wave voltammograms of 3 in the presence of $\mathrm{K}^{+}$. 


\section{General Experimental Methods}

All materials were standard analytical grade and used without further purification. Commercial grade solvents such as acetone, hexane, dichloromethane, methanol and ethyl acetate were distilled before used. Acetonitrile was dried over $\mathrm{CaH}_{2}$ and freshly distilled under nitrogen prior to use. THF was dried with sodium in benzophenone under nitrogen atmosphere and distilled before used. Column chromatography was carried out using silica gel (Kieselgel 60, 0.063-0.200 mm). Thin layer chromatography (TLC) was performed on silica gel plates (Kieselgel 60 F254, $1 \mathrm{~mm}$ ).

Nuclear Magnetic Resonance (NMR) spectra were recorded on either $200 \mathrm{MHz}$ or 400 $\mathrm{MHz}$ nuclear magnetic resonance spectrometer. In all cases, samples were dissolved in deuterated chloroform and chemical shifts were recorded in part per million (ppm) using a residual proton or carbon signals in deuterated solvents as internal reference. 

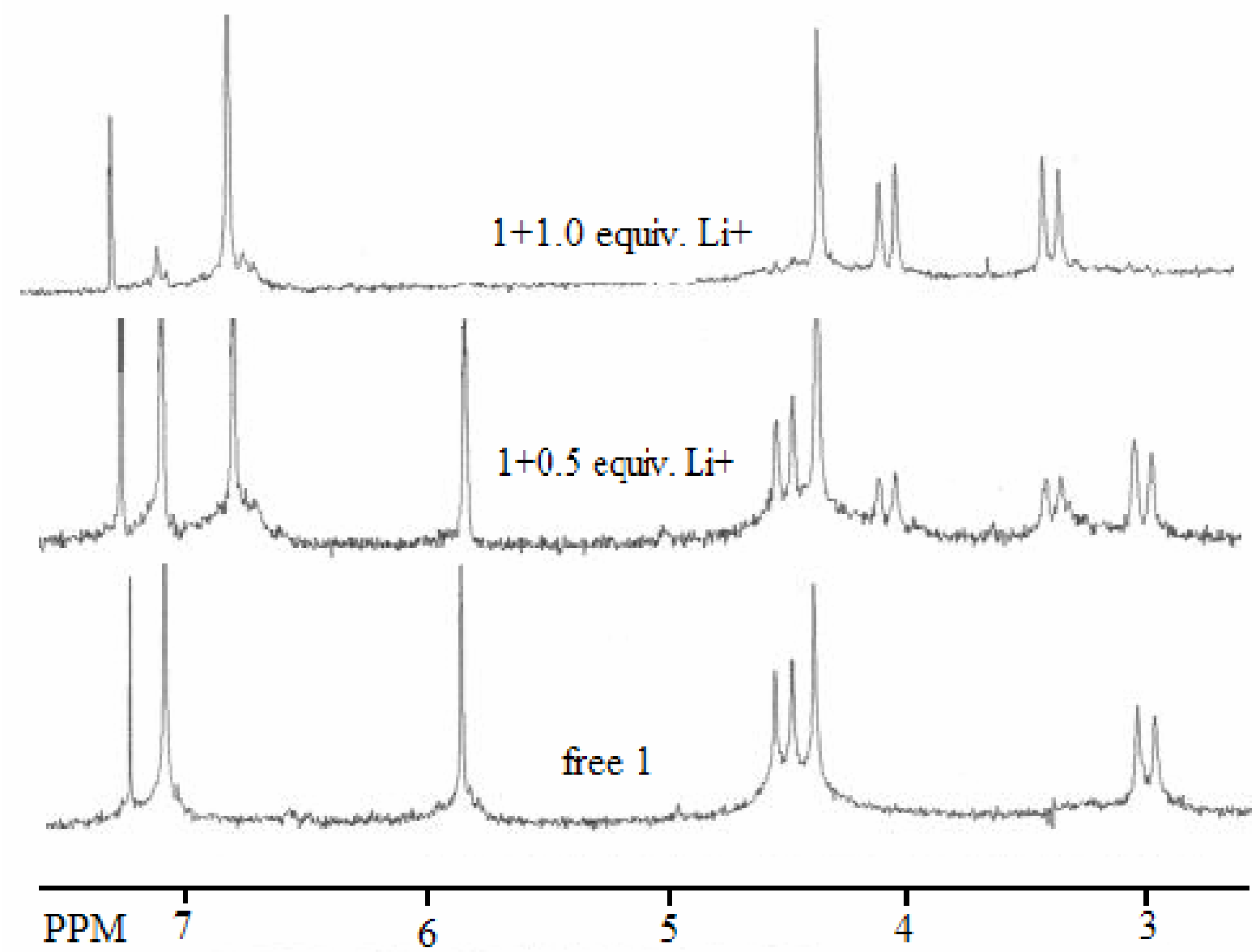

Fig S1. ${ }^{1} \mathrm{H}$ NMR (200 MHz) spectra of receptor 1 in the presence of $\mathrm{Li}^{+}$. 

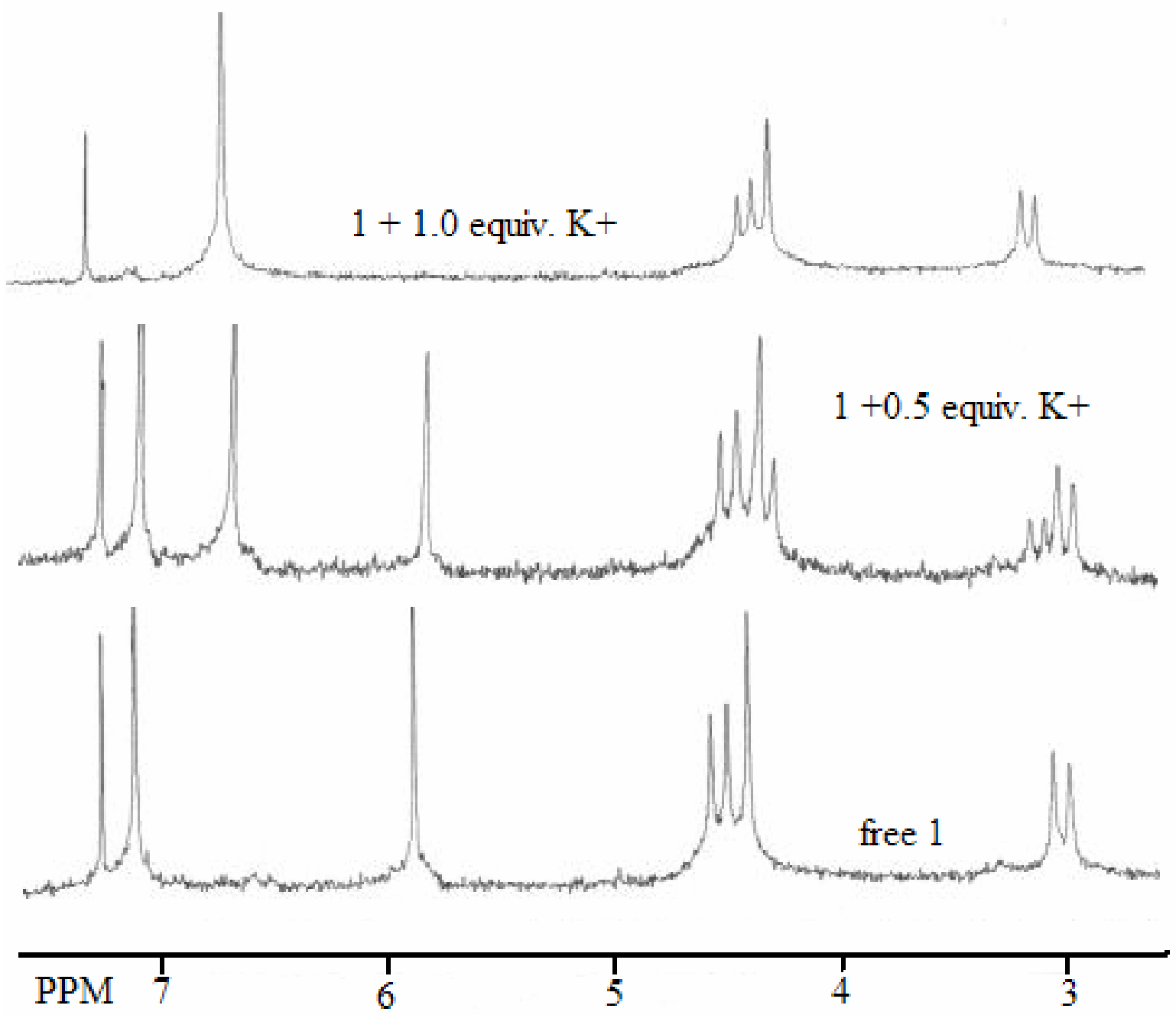

Fig S2. ${ }^{1} \mathrm{H}$ NMR $(200 \mathrm{MHz})$ spectra of receptor 1 in the presence of $\mathrm{K}^{+}$. 

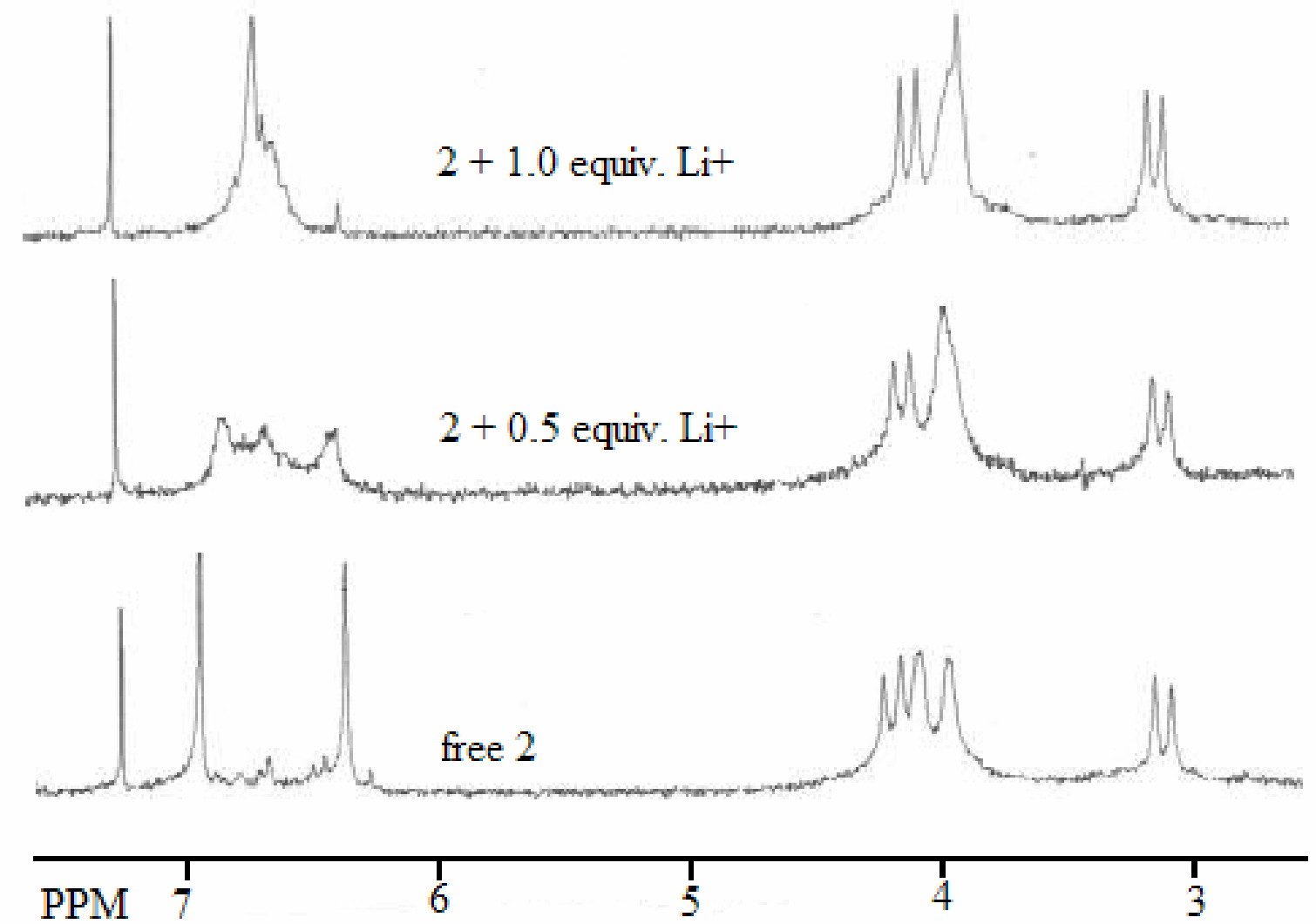

Fig S3. ${ }^{1} \mathrm{H}$ NMR $(200 \mathrm{MHz})$ spectra of receptor 2 in the presence of $\mathrm{Li}^{+}$. 


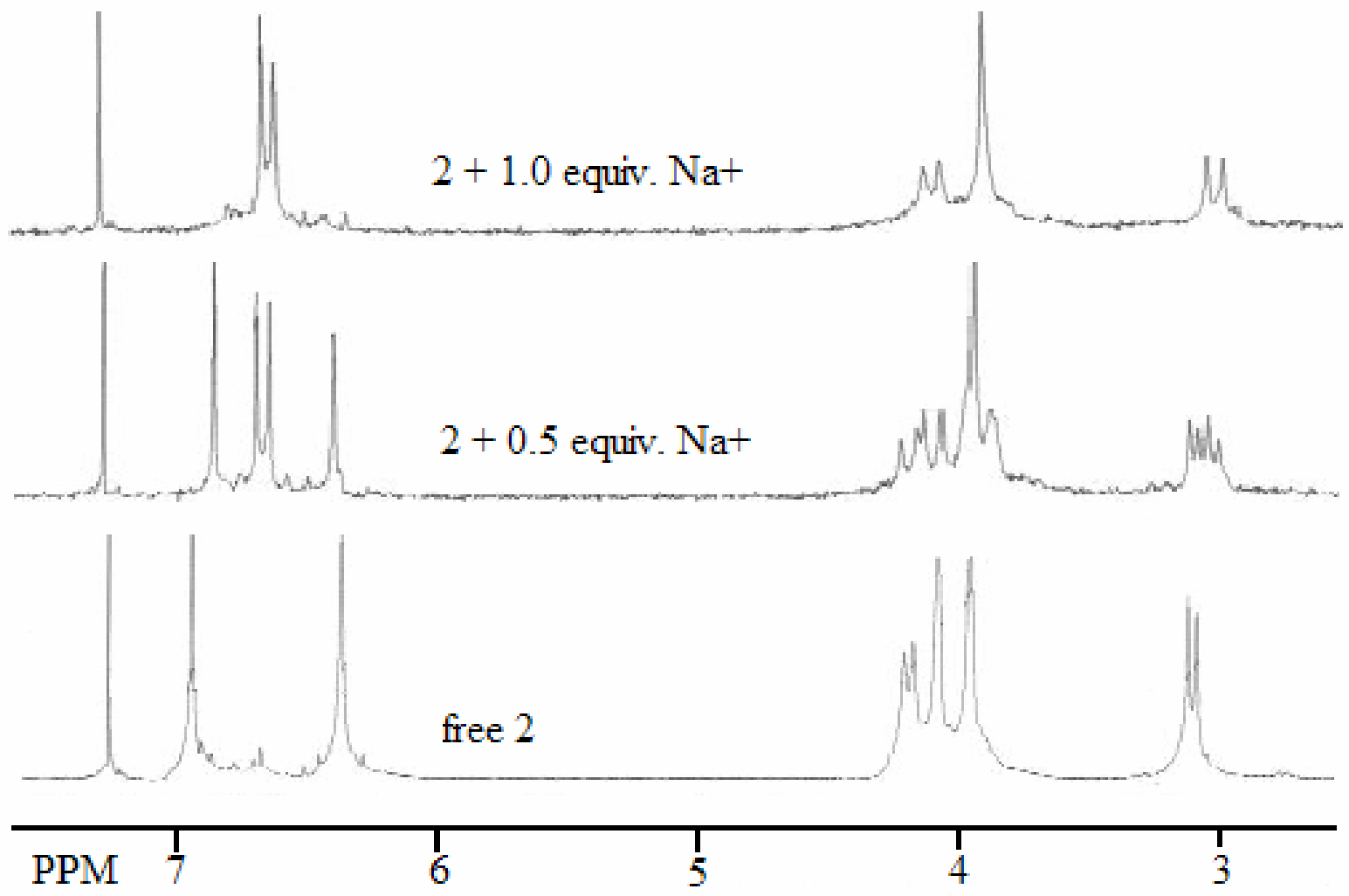

Fig S4. ${ }^{1} \mathrm{H}$ NMR (200 MHz) spectra of receptor 2 in the presence of $\mathrm{Na}^{+}$. 


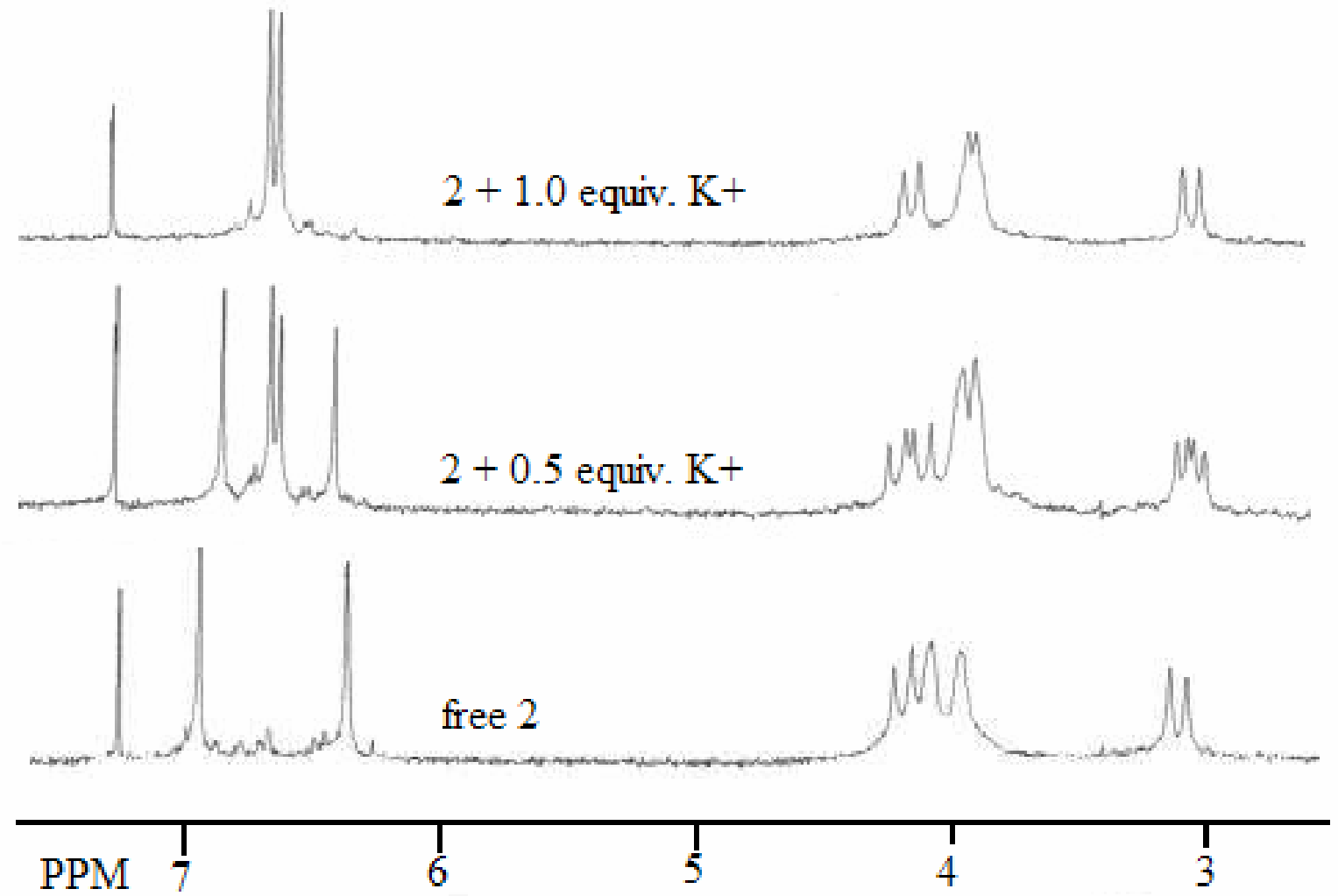

Fig S5. ${ }^{1} \mathrm{H}$ NMR $(200 \mathrm{MHz})$ spectra of receptor 2 in the presence of $\mathrm{K}^{+}$. 

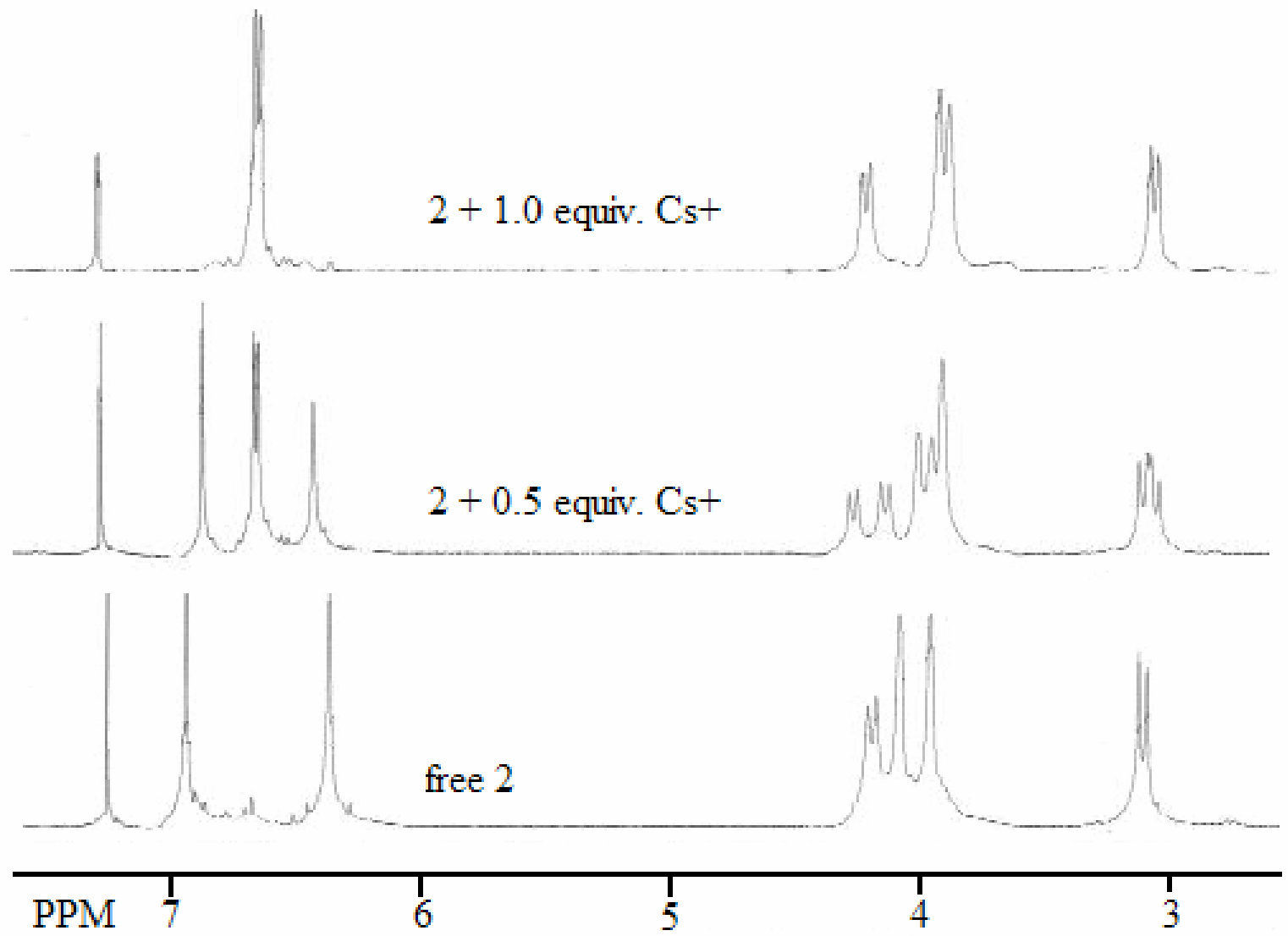

Fig S6. ${ }^{1} \mathrm{H}$ NMR $(200 \mathrm{MHz})$ spectra of receptor 2 in the presence of $\mathrm{Cs}^{+}$. 


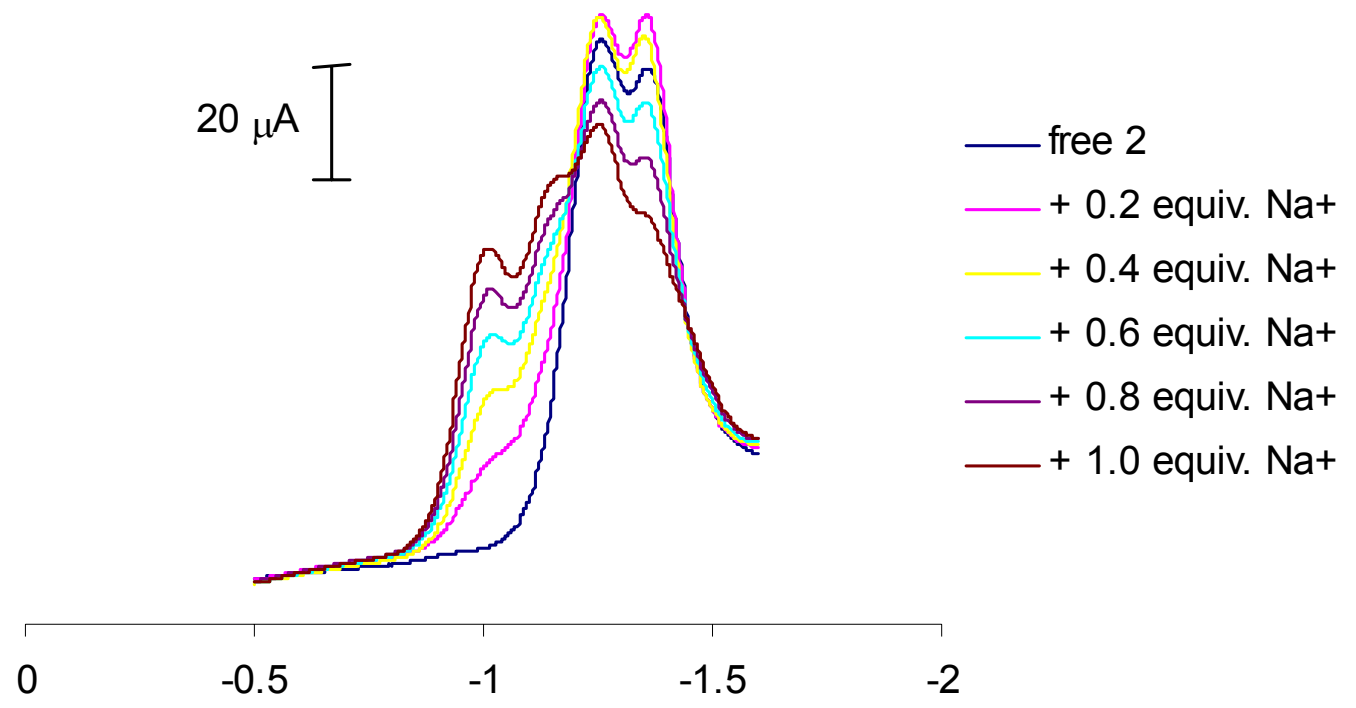

Fig S7. Square wave voltammograms of 2 in the presence of $\mathrm{Na}^{+}$. 


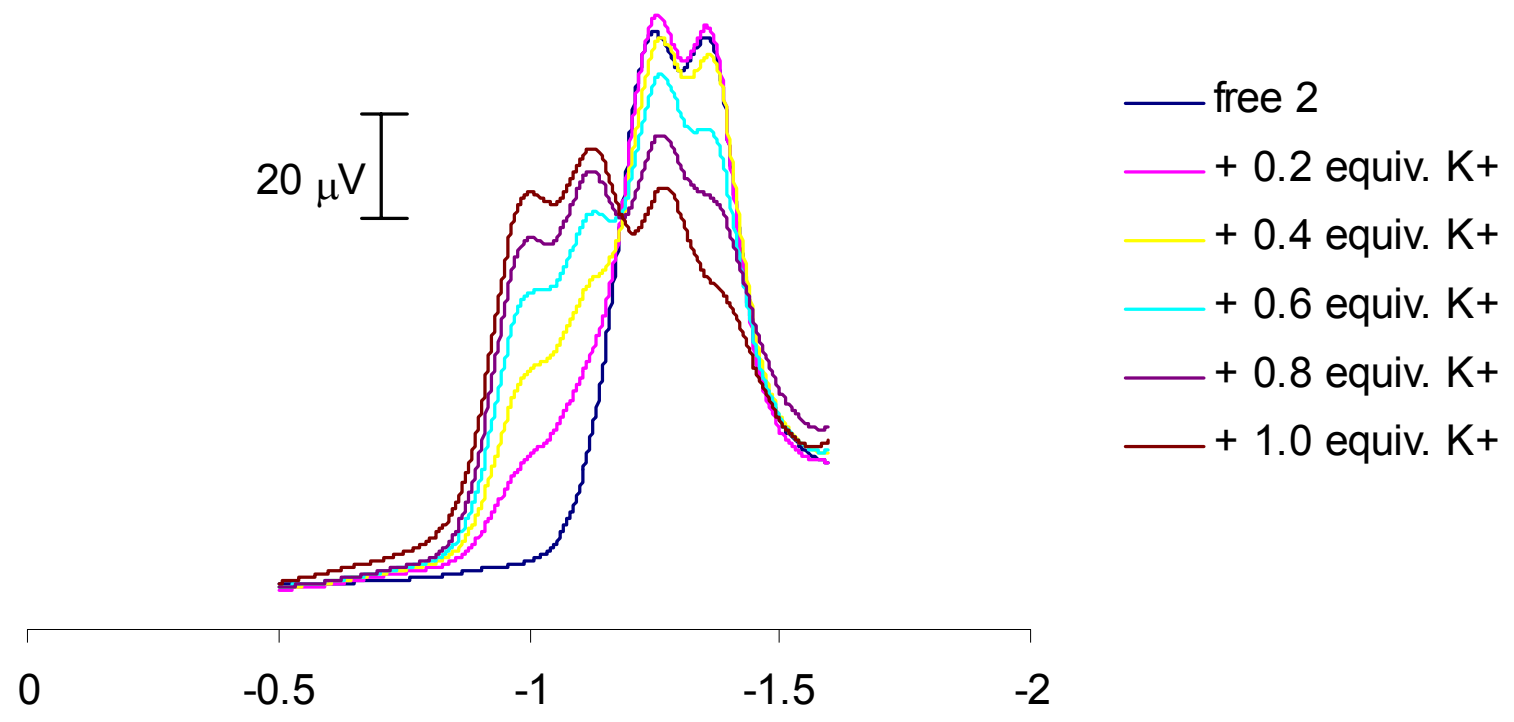

Fig S8. Square wave voltammograms of $\mathbf{2}$ in the presence of $\mathrm{K}^{+}$. 


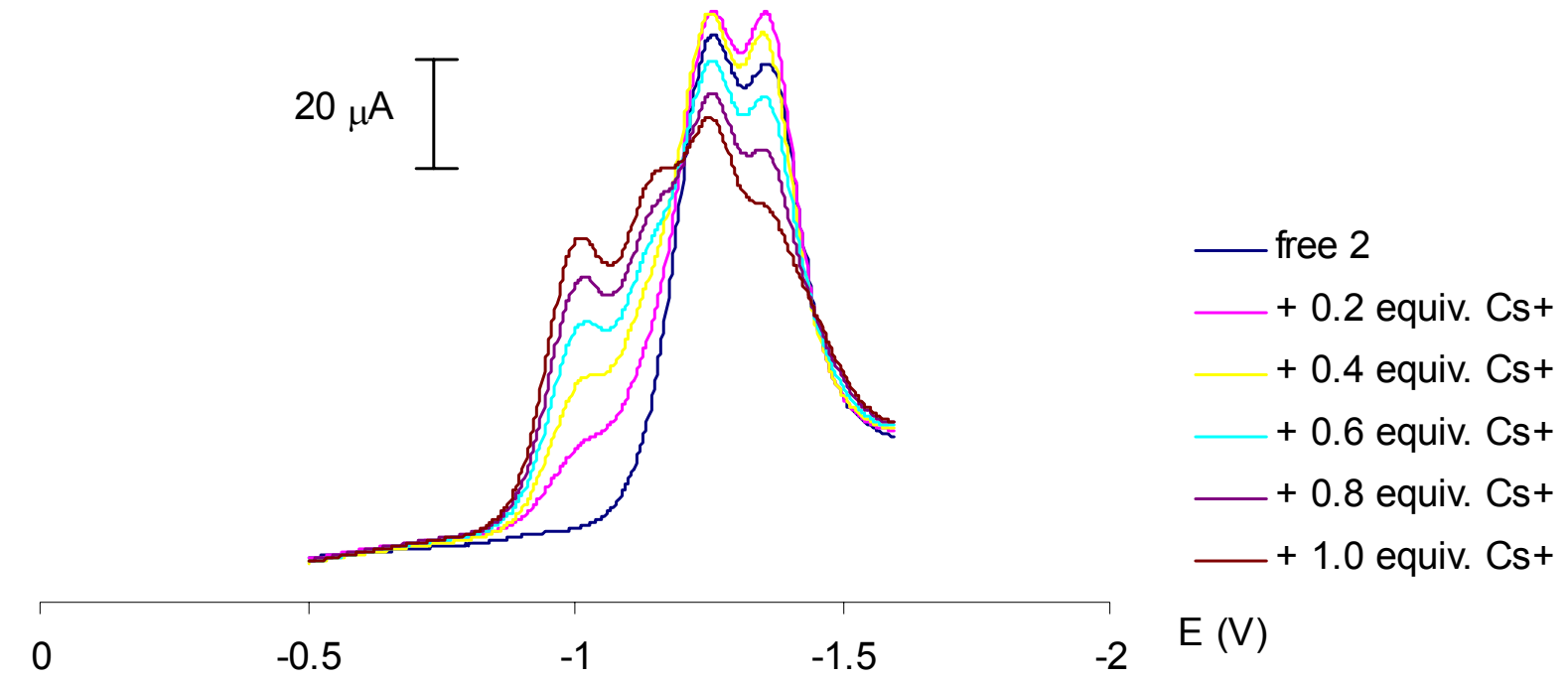

Fig S9. Square wave voltammogram of $\mathbf{2}$ in the presence of $\mathrm{Cs}^{+}$. 


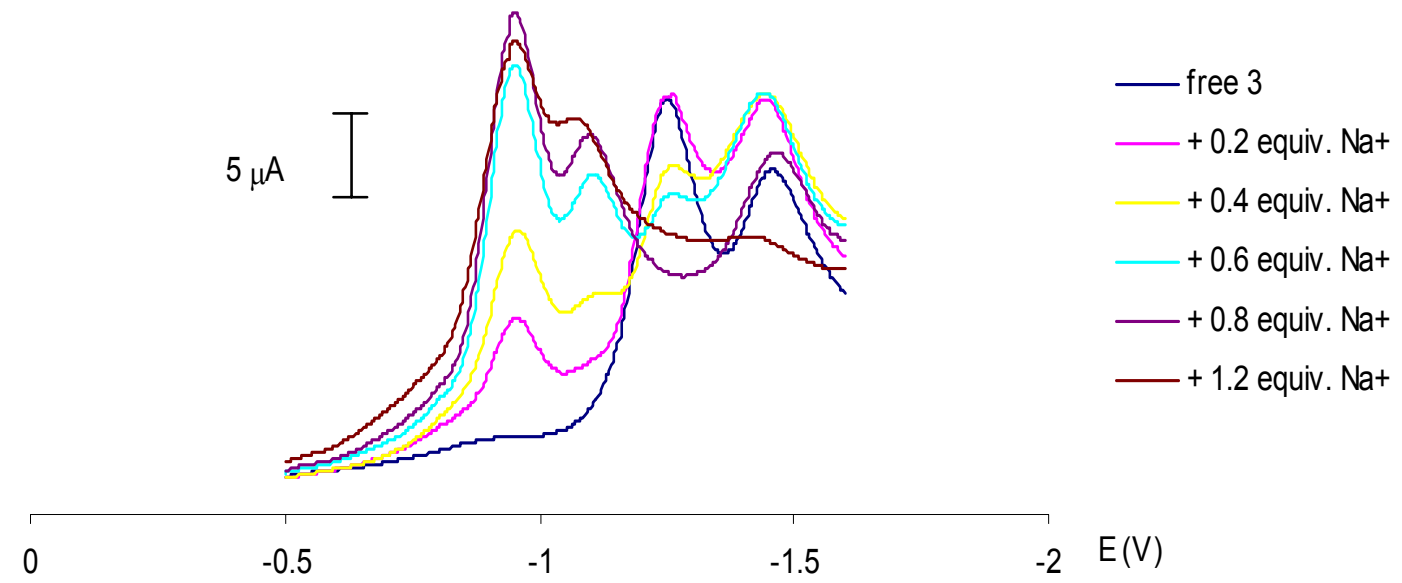

Fig S10. Square wave voltammograms of $\mathbf{3}$ in the presence of $\mathrm{Na}^{+}$. 


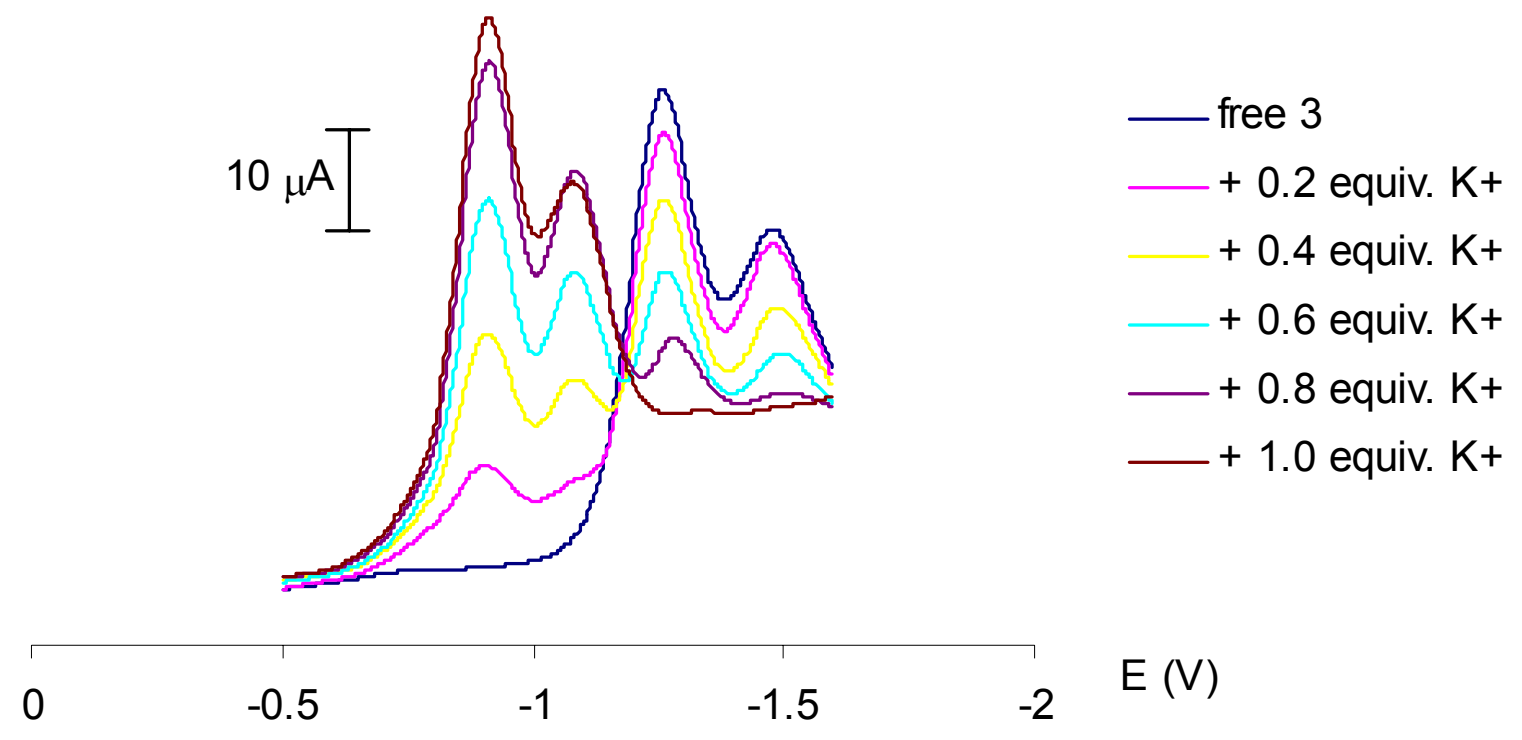

Fig S11. Square wave voltammograms of $\mathbf{3}$ in the presence of $\mathrm{K}^{+}$. 